\title{
KOMUNIKASI ANTARBUDAYA: AKULTURASI BAHASA DALAM MASYARAKAT PENDALUNGAN KABUPATEN JEMBER
}

\author{
Yunia Permadani Putri Efendi, Hery B. Cahyono \\ Ilmu Komunikasi Fakultas Ilmu Sosial dan Ilmu Politik \\ Universitas Muhammadiyah Jember, J1. Karimata No. 49 Jember \\ yuniaefendi@gmail.com, herybcahyono@gmail.com
}

\begin{abstract}
This study aims to determine the acculturation of inter-ethnic Javanese language and ethnic Madurese in Jember regency. This study uses qualitative research methods in descriptive form. The author raises the theme of acculturation Pendalungan culture is based on observations in the community of Pendalungan Jember which uses two languages at once when communicating. This uniqueness is the attraction of this new culture to be studied. Javanese culture and Madurese culture that merge into one and form a new culture gives color to cultural diversity in Indonesia. This unique Pendalungan dialect is only found in Jember Regency. The problem in this research is how the acculturation of Javanese language and Madurese language in Pendalungan culture, Factors that influence the occurrence of acculturation of Javanese and Madurese languages in Pendalungan culture, obstacles to the acculturation of Javanese and Madurese languages in Pendalungan culture. The results of this study indicate that the acculturation of Javanese and Madurese languages occurs due to migration of residents from other regions to Jember Regency. The cause of the acculturation of Javanese and Madurese languages in Jember is due to historical factors, social and economic contacts. Some obstacles to the acculturation of Javanese and Madurese languages in Jember are ethnocentric, native cultural backgrounds, and languages.
\end{abstract}

Keywords: Acculturation, Pendalungan Language, The Culture of Pendalungan Ethnic Javanese, Madura Ethnicity

\begin{abstract}
Abstrak
Penelitian ini bertujuan untuk mengetahui Akulturasi Bahasa antar etnis Jawa dan etnis Madura di Kabupaten Jember. Penelitian ini menggunakan metode penelitian kualitatif dalam bentuk deskriptif. Penulis mengangkat tema akulturasi budaya Pendalungan adalah berdasarkan observasi pada masyarakat Pendalungan Jember yang menggunakan dua bahasa sekaligus ketika berkomunikasi. Keunikan ini yang menjadi daya tarik kebudayaan baru ini untuk diteliti. Budaya Jawa dan budaya Madura yang melebur menjadi satu dan membentuk budaya baru memberikan warna pada keanekaragaman budaya di Indonesia. Dialek Pendalungan yang unik ini hanya ditemui di Kabupaten Jember saja. Masalah dalam penelitian ini adalah bagaimana akulturasi bahasa Jawa dan bahasa Madura dalam budaya Pendalungan, Faktor yang mempengaruhi terjadinya akulturasi bahasa Jawa dan Madura pada budaya Pendalungan, hambatan terjadinya akulturasi bahasa Jawa dan Madura pada budaya Pendalungan. Hasil penelitian ini menunjukkan bahwa akulturasi bahasa Jawa dan bahasa Madura terjadi karena migrasi penduduk dari daerah lain ke Kabupaten Jember. Penyebab terjadinya akulturasi bahasa Jawa dan Madura di Jember karena faktor sejarah, kontak sosial dan ekonomi. Beberapa
\end{abstract}


hambatan akulturasi bahasa Jawa dan Madura di Jember adalah etnosentris, latar belakang budaya asli, dan bahasa.

Kata Kunci: Akulturasi, Bahasa Pendalungan, Budaya Pendalungan, Etnis Jawa, Etnis Madura

\section{PENDAHULUAN}

\section{Latar Belakang Masalah}

Bahasa dan budaya saling berkaitan. Bahasa adalah sesuatu yang digunakan manusia untuk memahami kabudayaan. Dalam artian bahasa bisa mencerminkan suatu budaya tertentu, untuk mengetahui identitas suatu budaya tertentu. Setiap budaya pastilah memiliki ciri khas bahasa yang berbeda. Seperti Madura menggunakan bahasa Madura, Jawa menggunakan bahasa Jawa, begitu juga Pendalungan memiliki bahasa sendiri yaitu bahasa Pendalungan. Para ahli melihat adanya hubungan antara kebudayaan dan bahasa. Baik saling mempengaruhi atau hubungan timbal balik. Ketika kita menghubungkan bahasa dengan kebudayan kita akan menemui hal khusus yaitu bahasa dan persepsi kita tentang realitas. Bahasa mampu membawa kita memandang dan memahami realitas yang ada dengan cara tertentu tergantung pemahaman masing-masing orang.

Bahasa merupakan alat yang digunakan oleh masyarakat untuk berinteraksi dengan masyarakat lainnya. Setiap masyarakat memiliki bahasa sendiri yang digunakan untuk berkomunikasi. Sama halnya dengan masyarakat Pendalungan. Masyarakat Pendalungan adalah masyarakat yang unik, seperti yang sudah dipaparkan penulis mengenai apa itu Pendalungan, percampuran budaya yang terjadi pada masyarakat Pendalungan menghasilkan banyak keunikan salah satunya adalah bahasa. Bahasa yang digunakan masyarakat Pendalungan untuk berkomunikasi adalah bentuk dari akulturasi antara budaya Jawa dan budaya Madura. Umumnya masyarakat Pendalungan menguasai dua bahasa daerah yang dipaparkan penulis. Dalam kehidupan sehari-hari masyarakat Pendalungan terbiasa berinteraksi menggunakan dua bahasa tersebut, kebiasaan tersebut berlangsung berulangulang. Suatu kebiasaan yang dilakukan berulangkali akan menciptakan kebiasaan baru. Masyarakat Pendalungan terbiasa mencampur dua bahasa menjadi satu ketika berkomunikasi hingga memunculkan kedwibahasaan.

Jika kita membicarakan persoalan kedwibahasaan maka akan ada percampuran dua bahasa, bahasa ibu dan 
bahasa kedua. Hal ini terjadi ketika penutur bahasa memasukkan unsur-unsur bahasa lain kedalam bahasa utama. Misalnya masyarakat Pendalungan yang dominan menggunakan bahasa Jawa memasukkan unsur bahasa Madura kedalam sebuah percakapan. Begitu juga sebaliknya.

Alasan penulis mengangkat tema akulturasi budaya Pendalungan adalah berdasarkan observasi pada masyarakat Pendalungan Jember yang menggunakan dua bahasa sekaligus ketika berkomunikasi. Keunikan ini yang menjadi daya tarik kebudayaan baru ini untuk diteliti. Budaya Jawa dan budaya Madura yang melebur menjadi satu dan membentuk budaya baru memberikan warna pada keanekaragaman budaya di Indonesia. Dialek Pendalungan yang unik ini hanya ditemui di Kabupaten Jember saja. Peneliti ingin mengetahui lebih dalam apa yang menyebabkan terjadinya akulturasi bahasa pada masyarakat Pendalungan ketika berinteraksi satu sama lain. Penelitian ini perlu dilakukan untuk mengetahui apakah bahasa baru hasil percampuran antara bahasa Jawa dan bahasa Madura yang digunakan dalam percakapan sehari-hari masyarakat Pendalungan merupakan sebuah warisan budaya yang menjadi ciri khas budaya Pendalungan.

\section{Rumusan Masalah}

Bagaimana akulturasi bahasa Jawa dan bahasa Madura dalam budaya Pendalungan?

Faktor apa yang mempengaruhi terjadinya akulturasi bahasa Jawa dan Madura pada budaya Pendalungan ?

Apa hambatan terjadinya akulturasi bahasa Jawa dan Madura pada budaya Pendalungan ?

\section{Tujuan Penelitian}

Untuk mengetahui akulturasi bahasa Jawa dan bahasa Madura dalam budaya Pendalungan

Untuk mengetahui faktor apa yang mempengaruhi terjadinya akulturasi bahasa Jawa dan Madura pada budaya Pendalungan

Untuk mengetahui hambatan terjadinya akulturasi bahasa Jawa dan Madura pada budaya Pendalungan

\section{TINJAUAN PUSTAKA}

\section{Komunikasi Antarbudaya}

Dalam komunikasi antarbudaya terdapat model komunikasi antarbudaya seperti yang dikemukakan dalam buku komunikasi antar budaya oleh Mulyana dan Rakhmat dimana tiga budaya diwakili dalam model ini oleh tiga bentuk gambar yang tidak sama. Budaya A dan B hampir 
sama dan masing-masing diwakili oleh bidang segi empat dan bidang segi delapan tak beraturan yang hampir menyerupai segi empat. Budaya $\mathrm{C}$ sangat berbeda dari budaya A dan budaya B. Perbedaan yang menonjol tampak pada bentuk lingkaran pada budaya $\mathrm{C}$.

Berbicara mengenai budaya

Pendalungan Arifin

mengemukakan pendapat bahwa

Pendalungan merupakan budaya bentuk akulturasi dari budaya Jawa dan Madura, di wilayah kota Jember karena perpindahan penduduk di era penjajahan. Adapun Sutarto (dalam Hadi 2017) menjelaskan Pendalungan sebagai masyarakat berbudaya baru hasil percampuran dua budaya yaitu etnis Jawa dan etnis Madura berbagai hal seperti bahasa, adat-istiadat, dan kesehariannya pun berbeda. Pada intinya kedua ahli ini berpendapat bahwa budaya Pendalungan tidak hanya milik satu kebudayaan dominan. Budaya Pendalungan Jember memfokuskan pada pada percampuran dua kebudayaan yaitu Jawa dan Madura.

\section{METODE PENELITIAN}

\section{Jenis Penelitian}

Berdasarkan judul penelitian ini yaitu "Akulturasi Bahasa Dalam Masyarakat Pendalungan Jember" peneltian ini menggunakan metode deskriptif kualitatif.
Moleong dalam (Herdiansyah 2010:9) mendefinisikan penelitian kualitatif adalah penelitian yang memiliki tujuan untuk memahami masalah tentang apa yang dialami oleh informan penelitian, misalnya perilaku, persepsi, motivasi, tindakan, dan lain sebagainya. Penelitian diolah dengan cara deskripsi dalam bentuk kata-kata dan bahasa dengan menggunakan berbagai metode ilmiah.

\section{Lokasi Penelitian}

Penelitian ini dilaksanakan di Kabupaten Jember. Penelitian dilakukan di Kabupaten Jember karena di Kabupaten Jember terdapat dua etnis yang mendasari terjadinya akulturasi budaya Pendalungan di Jember yakni etnis Jawa dan etnis Madura. Penelitian dilakukan dengan jangka waktu waktu selama dua bulan. Dimulai pada bulan maret awal hingga bulan april akhir. Di antara kota-kota di Karesidenan Besuki pada desenia pertengahan abad ke 19 sampai awal abad 20, kota yang paling menarik pertumbuhannya adalah Jember. Kota ini semula sebagai kota kecil yang sepi serta kurang mendapat perhatian dan statusnya sebagai salah satu distrik dari Regentschap Bondowoso. Dalam waktu yang relatif singkat kota Jember menjadi kota yang paling besar jika dibanding dengan 
kabupaten-kabupaten di Karesidenan Besuki.

\section{Sumber Data}

Mengacu pada judul dalam penelitian ini, peneliti berusaha untuk mendeskripsikan, mengetahui, dan mengkaji tentang budaya Pendalungan. Sumber data dalam penelitian ini dibagi menjadi dua kelompok dimana setiap sumber data memiliki fungsi masingmasing, yaitu:

\section{Data Primer}

Data primer adalah yang langsung diperoleh dari sumber data pertama di lokasi penelitian atau objek penelitian (Ardial 2014: 359). Dalam penelitian ini berarti sumber data primer adalah budayawan yang paham mengenai budaya Pendalungan serta masyarakat Pendalungan. Peneliti melakukan wawancara dengan Bapak Y. Setiyo Hadi, Bapak Christanto Puji Raharjo, Bapak Juhanda, Ilham Zoebazary, dan Bapak Joko. Peneliti mempertimbangkan melakukan wawancara dengan narasumber di atas karena narasumber tersebut telah berkecimpung meneliti dan mengamati budaya Pendalungan sejak lama. Serta peneliti melakukan pengamatan pada masyarakat ketika mereka berkomunikasi menggunakan bahasa Pendalungan.

Data Sekunder
Data sekunder berasal dari data primer yang telah diolah lebih lanjut menjadi bentuk-bentuk seperti tabel, grafik, diagram, gambar, dan sebagainya (Ardial 2014: 360). Data sekunder dalam penelitian ini merupakan hasil olahan dari data primer yang telah didapat di lokasi penelitan serta rekaman wawancara masyarakat ketika berbicara menggunakan bahasa Pendalungan.

\section{Penentuan Sumber Data}

Metode Penentuan Informan pada penelitian ini yaitu menggunakan prosedur Snowball. Prosedur bola salju (snowball) juga dikenal sebagai prosedur "rantai rujukan" atau juga prosedur nerworkingsering dianggap pula jenis prosedur purposif. Namun sesungguhnya berbeda. Dalam prosedur ini, dengan siapa perserta atau informan pernah dikontak atau pertama kali bertemu dengan peneliti adalah penting untuk menggunakan jaringan sosial mereka untuk merujuk peneliti kepada orang lain yang berpotensi berpartisipasi atau berkontribusi dan mempelajari atau memberi informasi kepada peneliti (Bungin 2011: 108). Peneliti akan melakukan wawancara dengan 5 pengamat budaya.

\section{Metode Pengumpulan Data}

Metode pengumpulan data dilakukan dengan metode sebagai berikut: 
Tahap wawancara

Meliputi menyimak wujud kedwibahasaan tuturan informan, merekam tuturan informan, mencatat tuturan informan yang telah disimak dan direkam, menemukan dan menandai wujud kedwibahasaan tuturan informan, serta memasukkan data. Peneliti akan melakukan wawancara kepada narasasumber yang telah peneliti cantumkan pada data primer untuk memperoleh data valid terkait penelitian ini.

Tahap observasi nonpartisipan

Observasi nonpartisipan atau observasi tidak terstruktur merupakan observasi yang dilakukan tanpa menggunakan petunjuk observasi. Peneliti akan melakukan pengamatan pada objek tidak perlu memahami secara teoritis terlebih dahulu objek penelitian (Ardial 2014: 120). Pada penelitian ini peneliti akan langsung terjun ke tempat lokasi penelitan untuk melakukan observasi masyarakat Pendalungan ketika berkomunikasi menggunakan bahasa Pendalungan.

Tahap dokumentasi

Analisa Data

Analisis data dalam penelitian ini terdiri dari tiga tahap, yaitu reduksi data, penyajian data, penarikan kesimpulan (verifikasi) seperti yang dikatakan Miles dan Huberman (dalam Sugiyono, 2014:
246) yang disajikan secara deskriptif kualitatif dengan menggunakan informan dari etnis Jawa dan etnis Madura yang mengalami akulutasi bahasa.

Reduksi data

Reduksi data adalah kegiatan mengumpulkan, memilih, hal-hal yang pokok, memfokuskan pada hal-hal yang penting. Peneliti akan mengumpulkan semua data mengenai akulturasi bahasa pada masyarakat Pendalungan (wujud kedwibahasaan) yang telah dikumpulkan dalam proses pengumpulan data.

Penyajian data

Pada tahap ini peneliti akan memaparkan data penelitian yang telah direduksi. Data akan dipaparkan dengan rapi dalam bentuk tabel dan dideskripsikan.

Penarikan kesimpulan

Pada tahap ini penyimpulan data akan disimpulkan menurut teori yang digunakan. Penyimpulan data akan ditulis secara baik, singkat, padat, serta mudah dipahami.

\section{HASIL PENELITIAN DAN} PEMBAHASAN

Akulturasi Bahasa Jawa dan Bahasa Madura

Berdasarkan hasil wawancara dengan ketua komunitas Pendalungan Jember 
peneliti memperoleh data mengenai budaya Pendalungan Jember.

Keberadaan Bahasa Pendalungan

"Bahasa yang disebut bahasa Pendalungan harus mengetahui dulu sejarah Pendalungan itu apa. Jadi kalau kita melihat geografis di Indonesia itu, geografis di Indonesia itu khususnya pulau Jawa kita mengenal ada wilayah Pasundan. Wilayah Pasundan itu adalah meliputi wilayah Jawa Barat. Kemudian wilayah Mataraman, wilayah Mataraman itu adalah wilayah daerah Jawa Tengah. Kemudian ada masyarakat arek Mojokerto, Sidoarjo, Surabaya, Gresik itu adalah masyarakat arek. Pasuruan kesini sampai dengan ke Banyuwangi itu adalah masyarakat Pendalungan. Kenapa masyarakat Pendalungan karena mereka berangkat dari perpindahan penduduk migrasi penduduk yang awalnya wilayah Pendalungan pasuruan sini itu adalah wilayah yang baru dibuka. Mereka berbondong-bondong untuk datang itu karena wilayahnya jadi perkebunan. Nah otomatis disitulah percampuran nilai budaya itu menjadi satu termasuk kebahasaan." (hasil wawancara bapak Joko pada tanggal 12 Maret 2019).

Hasil observasi berdasarkan wawanncara di atas adalah bahwa geografis pulau Jawa kita mengenal wilayah pasundan meliputi wilayah Jawa Barat, kemudian wilayah mataraman meliputi wilayah Jawa Tengah, lalu ada masyarakat arek Mojokerto, Sidoarjo, Surabaya, dan Gresik. Wilayah Pasuruan hingga Banyuwangi merupakan wilayah Pendalungan. Kenapa disebut masyarakat
Pendalungan karena mereka berangkat dari perpindahan penduduk, migrasi penduduk. Yang awalnya wilayah Pasuruan hingga Banyuwangi adalah wilayah yang baru di buka. Mereka datang daerah Jember karena wilayah ini akan dijadikan perkebunan. Karena yang bermigrasi itu berasal dari berbagai etnis seperti masyarakat arek, Jawa, dan Madura maka terciptanya budaya Pendalungan. Jember masih belum bisa dilacak asal budayanya. Jember merupakan multikultural, ada banyak suku yang menempati Jember seperti Jawa, Madura, Bugis, Mandar, Cina, Arab. Tetapi yang mendominasi adalah Jawa dan Madura. Berdasarkan wawancara peneliti dengan pak Juhanda, beliau berpendapat

"Masyarakat dari berbagai etnis yang paling mempengaruhi budaya Pendalungan adalah Jawa dan Madura. Tetapi ketika masyarakat Jember berinteraksi dalam kehidupan sehari-hari maka secara otomatis terjadi akulturasi atau percampuran budaya secara tidak sadar." (hasil wawancara bapak Juhanda pada tanggal 23 Maret 2019).

Pendapat Pak Ilham mengenai Pendalungan hampir sama dengan pas Joko ketika diwawancara oleh peneliti di warung kember Ajung.

"Pendalungan itu ya khas tapal kuda mulai dari daerah ee terutama daerag pesisir 
timur ya seperti Banyuwangi utara terus Jember. Bukan Osing lo ya, Osing itukan sebagian aja. Jawa nya sudah bukan Jawa sungguhan tetapi Pendalungan, percampuran. Seperti disini. Memang agak berbeda antara, kalo Banyuwangi Jember Lumajang ini lebih terpengaruh ke Osing dan Mataraman. Kalo yang di Bondowoso Situbondo itu Pendalungannya terpengaruh lebih banyak dipengaruhi oleh Madura. Nanti yang pasuruan probolinggo itu lebih dipengaruhi oleh arek. Arek itu wilayah kebudayaan Surabaya dan sekitarnya. Saya kitra kata Pendalungan itu khas anuyaa.. khas Jawa Timur." (hasil wawancara bapak Ilham pada tanggal 12 Maret 2019).

Berdasakan wawancara bersama pak Ilham peneliti mendapatkan data yaitu Pendalungan adalah khas tapal kuda. Banyuwangi, Jember lumajang Pendalungannya lebih didominasi oleh suku Madura, suku Osing, dan suku Jawa mataraman. Bondowoso dan Situbondo lebih didominasi oleh Madura. Pasuruan dan Probolinggo lebih didominasi oleh masyarakat arek. Kata Pendalungan khas Jawa timur, di Jawa tengah menggunakan kata mendalungan. Pendalungan merupakan satu periuk besar atau dalung menurut Pak Ilham merupakan wadah masyarakat yang ridak memiliki keaslian suatu budaya.

Kosa Kata dan Logat Bahasa

Kosa Kata

Ciri khas budaya Pendalungan adalah percampuran antara budaya Jawa dan
Madura. Kalau berbicara Jember sebenarnya akulturasi budayanya bukan hanya Jawa-Madura saja. Tetapi ada etnis Arab etnis Cina serta Bugis dan lain-lain. Tetapi meski masyarakatnya terdiri dari latar belakang etnis yg berbeda ketika melakukan interaksi dan komunikasi tetap menggunakan bahasa yang sudah melekat di Jember yaitu bahasa Pendalungan. Ketika berkomunikasi menggunakan bahasa Jawa tetapi saat didengarkan oleh orang di luar Jember terkesan aneh seperti yang di contohkan oleh pak Joko

"Boh mak wes di deleh nang kunu wingi, aku kok ga eruh lek aku tak deleh kunu". (hasil wawancara bapak Joko pada tanggal 12 Maret 2019).

Kalimat seperti ini tidak ditemukan dimanapun. Kosa katanya menggunakan bahwa Jawa tetapi aksen nya seperti gaya Madura ketika didengarkan. Ketika seseorang dari etnis Jawa menikah dengan orang Jember atau orang Madura menikah dengan orang Jember. Atau etnis Jawa dan etnis Madura menikah dan hidup di Jember maka bahasa ibu masing-masing etnis akan sulit untuk bertahan dan melebur menjadi satu. kebanyakan bahasa yang digunakan adalah bahasa keseharian yaitu bahasa Pendalungan. Di bawah ini beberapa contoh penggunaan kosa kata khas Pendalungan. 
Logat Bahasa

Selain kosa kata, kekhasan bahasa Pendalungan adalah logat bahasa yang digunakan oleh masyarakat Pendalungan Jember.

"Penyebutannya istilah.. bukan kita mengatakan bahwa itu bahasa Pendalungan tetapi itulah bahasa yang terjadi kalo tadi bicara Pendalungan itu adalah percampuran asimilasi budayanya bukan kebahasaannya saja tetapi adat istiadat dan kebiasaan masyarakatnya pun menjadi bagian yang sama. Tidak lagi bercorak sangat Madura dan tidak lagi bercorak sangat Jawa. Nah percampuran. Jadi contoh sekarang bapaknya orang Jawa menikah dengan orang Madura atau menikah dengan orang Jember maka anakanak mereka tidak lagi mengenali bahasa Jawa dengan berbagai tingkatan atau bahasa Madura dengan berbagai tingkatannya. Dia mengenal bahasa kesehariannya." (hasil wawancara bapak Joko pada tanggal 12 Maret 2019).

Akulturasi bahasa antar etnis Madura dengan etnis Jawa di Kabupaten Jember menunjukkan bahwa terjadi perbedaan budaya dalam penggunaan bahasa pengantar karena kedua etnis membawa bahasa ibu dari daerah asal yaitu bahasa Madura dan bahasa Jawa. Dari tanggapan pak Joko ketika diwawancarai oleh peneliti berpendapat ada yang asli orang Jember menikah dengan suku lain dalam hal ini adalah suku Jawa akan menciptakan akulturasi secara tidak langsung melalui keturuan mereka. Mereka telah lama hidup di Jember sehingga secara tidak langsung telah terkontaminasi dengan kebudayaan yang ada di Jember yaitu budaya Pendalungan. Etnis Madura menggunakan bahasa Madura sebagai pengantar dan bahasa Indonesia sebagai bahasa pengganti karena sudah dimengerti oleh semua masyarakat terutama pada etnis Jawa. Etnis Madura menggunakan bahasa etnisnya sebagai bahasa pengantar utama ketika berkomunikasi dengan sesama orang dari etnis Madura. Sedangkan etnis Jawa ketika berkomunikasi dengan orangorang selain dari etnis Jawa cenderung menggunakan bahasa Jawa dengan tujuan mensosialisasikan langsung bahasa Jawa yang perlu diketahui etnis selain Jawa di daerah Kabupaten Jember. Adapun logat yang digunakan etnis Jawa ketika berkomunikasi sedikit banyak telah bercampur dengan logat Madura. Di bawah ini beberapa contoh percakapan menggunakan logat bahasa yang berbeda. Orang Jawa menggunakan logat Madura.

Faktor yang Mempengaruhi Akulturasi

\section{Bahasa Jawa dan Madura}

Melihat dari hasil wawancara di atas faktor sejarah, kontak sosial dan ekonomi menjadi penyebab terjadinya akulturasi bahasa Pendalungan Jember.

Faktor sejarah 
"Yang mewarnai itu ya dua etnis itu. Jawa dari selatan dan Madura dari utara. Itu jelas alurnya secara geografis bisa di pisahkan alurnya. Tetapi ketika mereka bertemu dengan berbagai kepentingan atau bekerja di Jember di kota apa sekolah apa menikah itu terjadi akulturasi namanya. Percampuran budaya itu secara tidak sadar. Maka Jember itu ya Jawa ya Madura. Ga jelas, Jawa ya gak jelas, Madura ya gak jelas." (hasil wawancara bapak Juhanda pada tanggal 23 Maret 2019).

"Yaitu tadi dari faktor kesejarahan. Faktor kesejarahan dimana ee masyarakat wilayah pasuruan sampai dengan sini itu adalah masyarakat migrasi yang tumbuh dan bertemu karena sesuatu hal." (hasil wawancara bapak Joko pada tanggal 12 Maret 2019).

"Bisa jadi mungkin kalau dilacak ke tahun ee disaat Belanda membuka perkebunan itu bisa saja. Jadi Belanda itu membutuhkan tenaga kerja to di dalam perkebunan itu apakah karet, kopi, cengkeh segala macem itu butuh e tampaknya memang ada beberapa atau banyak tenaga kerja yang di ambil dari pulau Madura untuk ditempatkan mungkin memang di wilayah-wilayah agak keras, kondisi alamnya agak keras maka Madura lebih cocok di letakkan disana oleh Belanda. Sementara perkebunan yang relatif tidak terlalu keras seperti tebu tembakau itu di wilayah Selatan itu ratarata orang Jawa." (hasil wawancara bapak Juhanda pada tanggal 23 Maret 2019).

Penyebab terjadinya akulturasi di Jember yaitu karena faktor sejarah. Jember terdiri dari masyarakat migrasi dari berbagai suku yang tumbuh dan berkembang bersama-sama dalam suatu wilayah sehingga segala aspek dalam budaya-budaya tersebut seperti adat istiadat, makanan, keseniaan dan juga bahasa bercampur menjadi satu. Budaya tidak bisa hari ini diciptakan dan pada hari ini jadi tetapi budaya terbentuk karena pergerakan masyarakat. Etnis Madura maupun Jawa mempunyai cara berbicara dan cara berbudaya sendiri. Ketika mereka bertemu mereka tidak bisa melepaskan/meninggalkan bahasa ibu mereka. Pada saat kedua etnis tersebut hidup dalam lingkungan yang sama maka keduanya saling mempengaruhi baik dari segi budaya maupun bahasanya. Percampuran bahasa terjadi pada masa kolonial belanda. Pada masa itu belanda mengambangkan perkebunan di Jember dan membutuhkan banyak pekerja. Untuk menyiasati hal tersebut belanda mengambil pekerja dari Madura untuk ditempatkan di wilayah yang agak keras (pegununan). Dan juga mengambil pekerja dari suku Jawa untuk ditempatkan di daerah perkebunan yang memproduksi tanaman yang dihidup didaerah yang lebih mudah seperi tebu dan tembakau (di daerah selatan seperti kencong tanggul). Menelisik secara historis Jember merupakan daerah baru. Jember pada masa itu selain dikenal sebagai daerah perkebunan juga dikenal sebagai daerah 'pembuangan' beberapa masyarakat untuk ditempatkan di wilayah perkebunan. 
Beberapa orang terbuang berasal dari etnis yang berbeda-beda. Hal tersebut yang menjadi salah satu penyebab terjadinya akulturasi. Dikaji lebih dalam lagi, perkebunan di Jember berkembang pesat pada masa penjajahan. Di utara banyak didatangkan orang Madura, di selatan banyak orang Jawa. Di tengah-tengah lah terjadi percampuran budaya dan terbentuk budaya Pendalungan.

Kontak sosial

"Ketika mereka bertemu dengan berbagai kepentingan apa bekerja di Jember, di kota, apa sekolah, apa menikah itu terjadi akulturasi namanya, percampuran budaya secara tidak sadar." (hasil wawancara bapak Juhanda pada tanggal 23 Maret 2019).

Kontak sosial juga menjadi salah satu penyebab terjadinya akulturasi bahasa pada masyarakat Pendalungan Jember. Semakin seseorang atau kelompok melakukan interaksi dengan yang lainnya maka sedikit banyak pasti kedaunya akan saling mempengaruhi satu sama dengan lainnya. Kontak budaya antar kelompok di mana ada kelompok yang menguasai dan ada yang dikusaai dalam semau unsur budaya yang ada dalam berbagai bidang seperti ekonomi, teknologi, ilmu pengetahuan maupun keagamaan dan lain - lain. Akulturasi memberi dampak yang besar terhadap kehidupan di Jember. Hal ini dapat menyebabkan terjadinya percampuran antara dua atau lebih kebudayaan. Sebelum tinggal di Jember masing-masing etnis akan menggunakan bahasa ibu mereka untuk berkomunikasi tetapi setelah tinggal dan menetap di Jember mau tidak mau mereka harus beradaptasi dengan lingkungan baru dengan berusaha menyesuaikan penggunakan bahasa dalam kehidupan sehari-hari mereka.

Faktor ekonomi

"Sekarang kalau kamu ada di pasar jompo misalkan ketemu orang yang sangat maduranya, cek medurone bisa jadi dia berbahasa Indonesia untuk ngobrol dengan orang lain tapi bisa jadi dia ngimbangi dengan bahasa Jawa juga. Sekarang liat orang Cina yang ada di toko-toko di jompo sana mereka menggunakan bahasa Madura dia juga menggunakan bahasa Jawa". (hasil wawancara bapak Joko pada tanggal 12 Maret 2019).

Faktor ekonomi. Di wilayah Jember perkembangan ekonominya cukup berkembang. Di pasar Jember dihuni berbagai pedagang dari bermacam-macam etnis. Ada dari etnis Jawa, etnis Madura, etnis Cina, etnis Arab, dan masih banyak lagi. Orang dari etnis Cina yang berprofesi sebagai pedagang di pasar jompo mau tidak mau harus mempelajari bahasa Jawa dan Madura agar transaksi dengan masyarakat sekitar bisa berjalan lancar. 


\section{Hambatan Terjadinya Akulturasi}

\section{Bahasa Jawa dan Bahasa Madura}

Etnosentris

" Oh iya itu sebenarnya tidak terhindarkan ya, tetap terjadi. Ada orang-orang yang cenderung eee menghilangkan jejak. Seperti misalnya begini orang-orang Jawa beranggapan bahwa etnis Jawa itu lebih tinggi dari etnis Madura. Etnosentris ya, etnosentrisme orang Jawa itu sangat tinggi. Sementara sebaliknya orang-orang Madura menganggap bahwa dirinya lebih rendah, jadi mereka merasa bahwa etnis Madura itu lebih rendah daripada etnis Jawa. Maka tidak mengherankan jika di Jember ini ada orang-orang yang berusaha menghilangkan jejak kemaduraannya. orang-orang Jawa membatasi sebisa mungkin tidak menggunakan bahasa Madura." (hasil wawancara bapak Ilham pada tanggal 12 Maret 2019).

Beberapa orang Jawa menganggap etnis Jawa lebih tinggi kastanya dari etnis Madura. Sementara orang Madura menganggap bahwa mereka lebih rendah dari orang Jawa. Beberapa orang Madura ada yang secara sengaja 'menghilangkan jejak' atau lebih mudahnya kita menyebut mereka tidak mau mengakui kemaduraannya. sedangkan orang dari suku Jawa membatasi sebisa mungkin tidak menggunakan bahasa Madura. Dari hasil pengamatan peneliti hampir semua etnis Jawa cenderung menolak untuk menggunakan bahasa Madura. Cara yang ditempuh etnis Jawa untuk membaur dengan suku Madura adalah menyisipkan istilah-istilah Pendalungan. Sedangkan etnis Madura masih mau belajar tentang bahasa Jawa dan mengaplikasikannya dalam kehidupan sehari-hari. Fenomena tersebutlah yang menjadi salah satu alasan terjadinya akulturasi bahada di Kabupaten Jember. Etnis Jawa tetap bisa memahami ketika berkomunikasi etnis Madura begitu juga sebaliknya etnis Madura bisa memahami etnis Madura. Kedua etnis dominan tersebut menggunakan bahasa Pendalungan untuk mengawali komunikasi dengan mereka dan bisa menJawab dengan menggunakan bahasa tersebut.

Latar belakang budaya asli

"Kalau dari masyarakat contoh disebuah perumahan dia mengambil perumahan yang sama disitu Madura disini Jawa disini Batak orang ngga akan peduli gitu lo. Dia ngga akan peduli lagi." (hasil wawancara bapak Joko pada tanggal 12 Maret 2019).

Latar belakang budaya asli memberi dampak terhambatnya proses akulturasi bahasa pada masyarakat Pendalungan Jember. Beberapa orang dari etnis Jawa yang masih memegang teguh budaya aslinya tidak mau menggunakan bahasa Madura sama sekali karena menurut mereka hal itu seperti membelot kepada budaya lain begitu juga sebaliknya.

Bahasa 
"Ketika mereka bertemu mereka tidak bisa eee meninggalkan atau melepaskan bahasa yang sudah menjadi bahasa ibu atau bahasa kesehariannya. Jadi tetep terbawa." (hasil wawancara bapak Ilham pada tanggal 12 Maret 2019).

Bahasa menjadi identifikasi atau cara masyarakat bersosialisasi dengan masyarakat lain. Ketika masing-masing orang yang berasal dari latar belakang etnis yang berbeda tidak mau bersosialisasi dengan masyarakat lain hal ini menggunakan bahasa keseharian dimana mereka menetap dan tinggal akan menjadi penghambat terjadinya akulturasi bahasa.

\section{KESIMPULAN DAN SARAN}

\section{Kesimpulan}

Hasil dari analisis penelitian yang telah dilakukan oleh peneliti mengungkapkan fakta bahwa sebenarnya bahasa Pendalungan itu masih belum ada di Jember. Karena secara definisi dan tatanan bahasa, bahasa Pendalungan belum terbentuk. Bahasa Pendalungan hanyalah sebagai sebutan saja untuk memudahkan masyarakat menganalisis istilah-istilah atau ungkapan ekspresi ketika masyarakat Pendalungan berkomunikasi. Bahasa Pendalungan merupakan bahasa yang keluar atau muncul sendiri. Belum ditemukan seseorang yang memang menciptakan bahasa Pendalungan. Sejauh ini peneliti yang meneliti mengenai Pendalungan belum ada yang menemukan pencipta bahasa Pendalungan. Karena pada dasarnya budaya tercipta karena kebiasaan yang dilakukan secara berturut-turut dan pada akhirnya dijadikan sebuah identitas suatu budaya. Cara komunikasi masyarakat Pendalungan yang unik inilah yang menguatkan bahwa budaya Pendalungan memang berkembang dan tumbuh di Kabupaten Jember.

\section{Saran}

Bagi pembaca hasil penelitian ini diharapkan dapat menambah wawasan pengetahuan terkait dengan budaya dan bahasa Pendalungan serta faktor-faktor yang mempengaruhinya dan juga faktorfaktor yang menghambat terjadinya akulturasi.

Bagi peneliti lain bisa dijadikan sebagai tambahan sumber data dan jika berminat untuk mengetahui lebih jauh tentang budaya dan bahasa Pendalungan (melakukan penelitian) maka perlu modifikasi rumusan masalah yang akan diteliti sehingga akan lebih objektif dan bervariasi dalam melakukan penelitian.

$$
\text { Bagi pemerintah, peneliti }
$$
menyampaikan saran-saran kepada pemerintah Kabupaten Jember untuk mendukung dan memfasilitasi segala 
kegiatan yang berkaitan dengan penelitian terkait budaya Pendalungan.

\section{DAFTAR PUSTAKA}

Arifin, Edy Burhan. 2006. Pertumbuhan Kota Jember dan Lahirnya Budaya Pandhalungan. Makalah disampaikan dalam Konferensi Nasional Sejarah VIII, Jakarta.

Ardial. Paradigma dan Model Penelitian Komunikasi. Bumi Asara: Jakarta. 2014.

Bungin, Burhan. Penelitian Kualitatif Komunikasi, Ekonomi, Kebijakan Publik, dan Ilmu Sosial Lainnya. Kencana Prenada Media Group: Jakarta. 2007.
Hadi, Y. Setiyo. Asal Usul Pandhalungan. Salam Nusantara: Jember. 2017.

Herdiansyah, Haris. Metodologi Kualitatif untuk Ilmu-Ilmu Sosial. Salemba Humanika: Jakarta. 2010.

Mulyana dan Rakhmat. Komunikasi Antarbudaya Panduan Berkomunikasi dengan OrangOrang Berbeda Budaya. PT Remaja Rosdakarya: Bandung. 2000.

Komunikasi Antarbudaya Panduan Berkomunikasi dengan OrangOrang Berbeda Budaya. PT Remaja Rosdakarya: Bandung. 2006.

Sugiyono. Metode Penelitian Pendidikan Pendekatan Kuantitatif, Kualitatif, dan R\&D. Alfabeta: Bandung. 2014. 